\title{
EVALUATION OF THE PERFORMANCE BETWEEN POST PROCESS KINEMATIC AND STATIC TECHNIQUE IN THE FOREST ENVIRONMENT
}

\section{PROCJENA USPJEŠNOSTI POSTPROCESNE KINEMATIČKE I STATIČKE TEHNIIKE U ŠUMSKOM OKRUŽENJU}

\author{
Atinç PIRTI, Ramazan Gürsel HOŞBAŞ
}

\begin{abstract}
SUMIMARY
A GNSS involves a constellation of satellites orbiting Earth, continuously transmitting signals that enable users to determine their three-dimensional (3D) position with global coverage. The positioning principle is based on solving an elemental geometric problem, involving the distances (ranges) of a user to a set of at least 4-5 GNSS satellites with known coordinates. These ranges and satellite coordinates are determined by the user's receiver using signals and navigation data transmitted by the satellites; the resulting user coordinates can be computed to an accuracy of several metres. However, centimetre-level positioning can be achieved using more advanced techniques (kinematic). GPS/GLONASS technique is becoming compulsory for many applications concerning forest management and inventory. This paper aims to comparing the coordinates resulted from Post Process Kinematic with the resulted coordinates for the same points resulted from static technique. Nonetheless, it appears that forest measurements with $\pm 1 \mathrm{~cm}$ accuracy cannot be guaranteed on all occasions, since difficult situations may lead to greater errors (about $\pm 10 \mathrm{~cm}$ accuracy for horizontal components and about $\pm(20-100) \mathrm{cm}$ accuracy for vertical components).
\end{abstract}

KEY WORDS: Post Process Kinematic, Static, Forest, Accuracy, Precision

\section{INTRODUCTION}

\section{UVOD}

Utilization of the GNSS technology is current topic. This technology appears to be as the most advantageous at densifying of the geodetic points in open areas, forest rides and forest stands borders with following measurement under the forest stand canopy by classic terrestrial methods. Results of the GNSS measurements are dependent on the method of measurement, length of the observation, satellite system, number, type and position of the satellites. At forest mapping as the most advantageous appears the static method of the GNSS. In the forest stands conditions at the kinematics (Real-Time Kinematic) and also at the Stop and Go method of the GNSS is coming to higher fluctuations of the errors in position (tenths of centimetres), hence there is no possibility of utilization of these methods at point fields creation, at property boundaries surveying with the fourth class of the mapping accuracy, which is required as the minimum. Also next factors have an influence on the measurement, for example type of the forest stand, mean thickness, canopy, and crop density. Influence has also season and location of the measured points in terrain. Here takes a role terrain configuration, exposure, appearance of 
shading trees close to measured point. At point fields densifying it is important to pay an attention on the optimal point arrangement. Points should be placed in open areas (borders of the forest stands, forest rides), to have secured an optimal signal receiving, but also with the optimal possibility of the projected point field utilization for next terrestrial measurements (El-Mowafy 2000), (Kaartinen et all 2015), (Pirti 2013), (Pirti 2016), (Pirti 2005), (Pirti 2008), (Wright et all 2017).

Kinematic surveying can provide immediate results using the real-time kinematic (RTK) mode or in the office using the post-process kinematic (PPK) mode. In post-processed kinematic (PPK) surveys, the collected data are stored on the survey controller or receiver until the fieldwork is completed. The data are then processed in the office using the same software and processing techniques used in static surveys. Data latency is not a problem in PPK surveys since the data is post processed. Other advantages of PPK surveys are that (1) precise ephemeris can be combined with the observational data to remove errors in the broadcast ephemeris and (2) the base station coordinates can be resolved after the fieldwork is complete. Thus, the base station's coordinates do not have to be known prior to the survey. The lack of data latency and use of a precise ephemeris results in PPK surveys having slightly higher accuracies than those obtainable from RTK surveys. After the data is collected, it is loaded into the processing software. An advantage PPK surveys have over RTK surveys is that precise ephemeris can be used in the processing (Kaartinen et all 2015), (El-Mowafy), (Wolf 2008).

Forest canopy affects the GNSS signals because of obstruction, attenuation, and reflection. So, line-of-sight GNSS signals are obstructed by solid objects. The signal is blocked by tree trunks, larger branches, and terrain features such as mountains. The signals are weakened and attenuated by leaves and small branches. This attenuation can make it very difficult for a GNSS receiver to track the signals. At some point, the receiver will not be able to track the signal at all and the effect will be the same as if the signal was obstructed. Even if the signal can be tracked, some receivers will have difficulty in measuring the pseudoranges accurately. The phenomenon of a satellite signal reaching an antenna by more than one path (direct and some reflected paths) is called multipath. This multipath can cause large variations in position estimates in a variety of environment, e.g., under forest canopy. Modern GNSS systems have been improved for the satellite tracking technology so that weaker signals can be observed under trees with foliage (Note that dense foliage will still cause cycle slips). In spite of this advanced tracking capability, the signals are noisier, weaker and more likely to be subject to multipath and diffraction. The surveyor should be aware that positions may not be accurate despite the quality indicators showing good solutions (Kaartinen 2015), (Wright 2017), (Pirti 2016), (Pirti 2005), (Pirti 2008), (Pirti 2010). The aim of this study is to assess the achievable accuracy of PPK surveys in the forest area.

\section{MATERIALS AND METHODS MATERIJALI I METODE}

The work was performed in Turgutlu, Manisa, Turkey (Figure 1). The site was selected in the Derbent-Çamlik Forest District, Turgutlu. The four points (P5, P6, P7 and P8) were marked in Derbent-Çamlık District, in the forest area. The four points were selected with the intention of achieving maximally different measurement conditions, See Figures 2 and 3 . This means that points were selected in both normal and difficult survey conditions. The four points to be measured were fixed with either asphalt nails. All static GNSS surveys were performed using four Satlab SL600 receivers. A static GNSS survey was performed in order to determine the coordinates of these four points. The surveys in this primary network were carried out with at least 5 hours (10:30-15:30) of observation times. The minimum
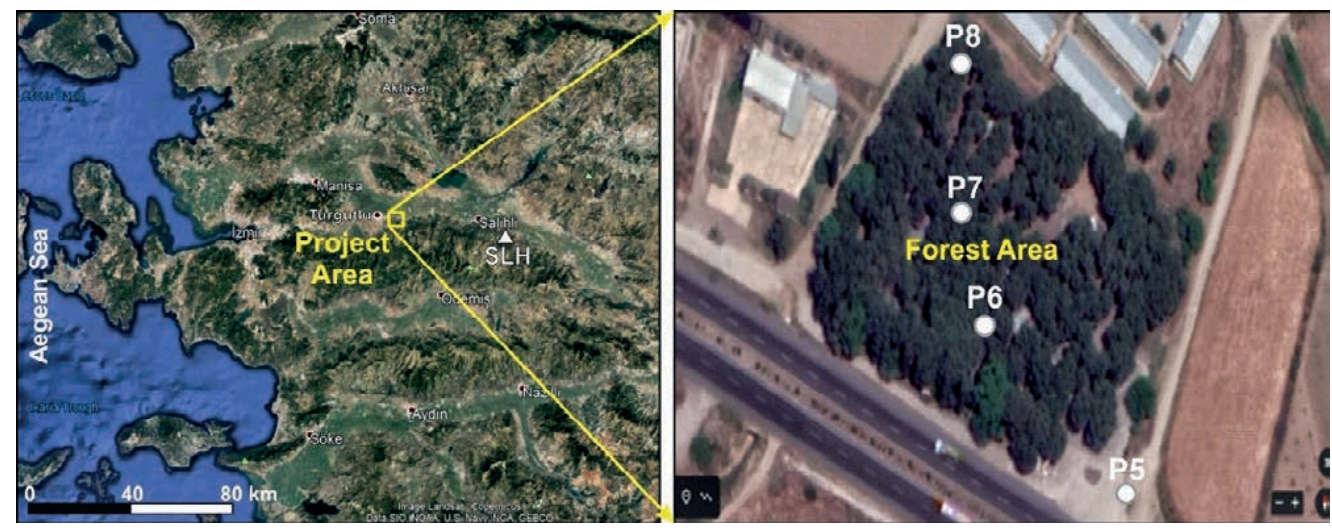

Figure 1. Project area and four points (P5, P6, P7 and P8) in the forest area Slika 1. Područje projekcije i četiri točke (P5, P6, P7 i P8) u šumskom području 

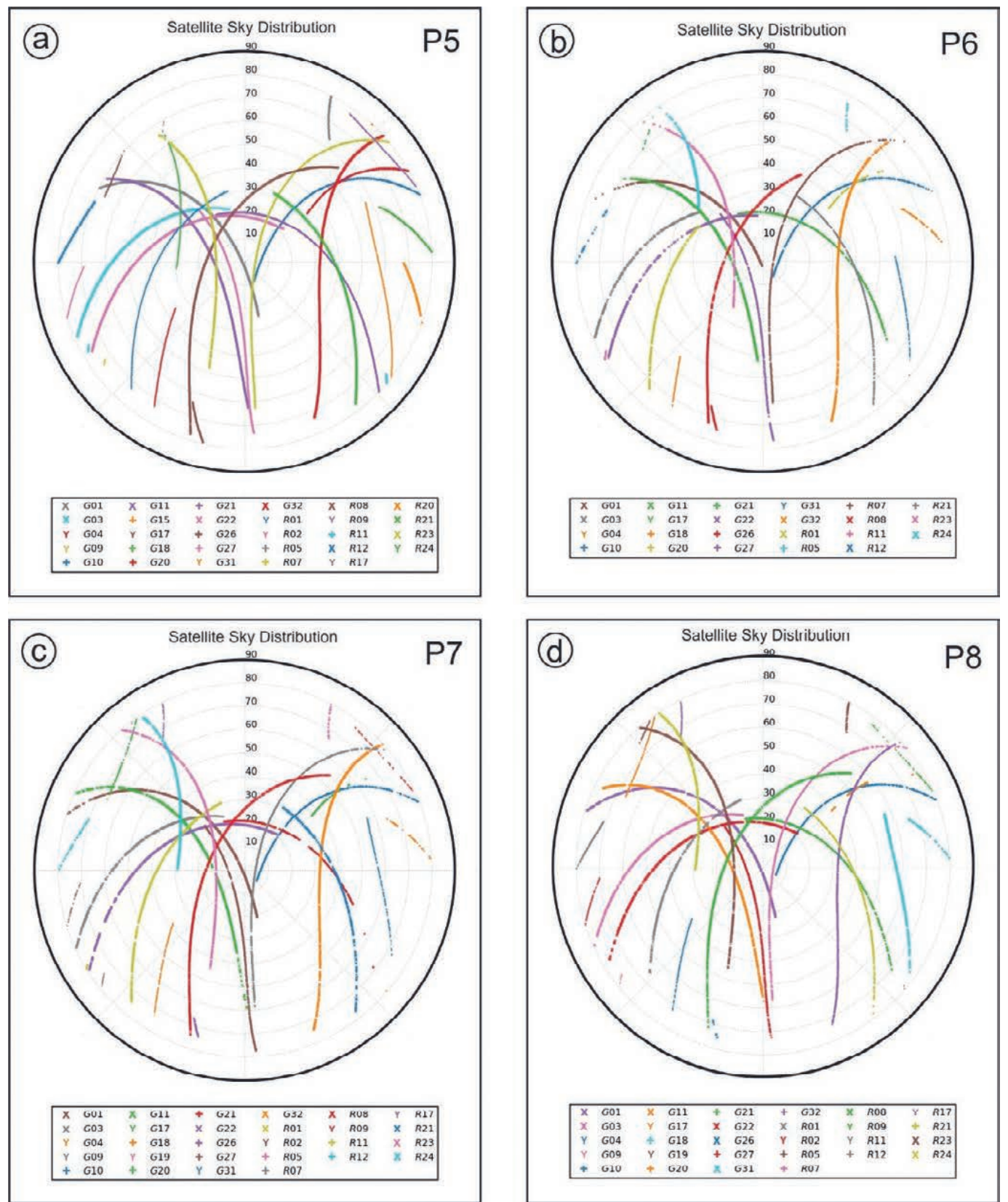

Figure 2. Skyplot at P6 (b), P7 (c) and P8 (d), strong obstruction by the trees; skyplot at P5 (a) in the unobstructed area between 10:30-15:30 hours. Slika 2. Skica satelita na P6 (b), P7 (c) i P8 (d), s velikim smetnjama od stabala; skica satelita na P5 (a) u neometanom području od 10:30 do 15:30 sati.

elevation cut-off angle and the sample rate were 10 degrees and 30 seconds, respectively. The performance specifications of the Satlab SL600 receivers are $8 \mathrm{~mm}+1.0 \mathrm{ppm}$ for horizontal and $15 \mathrm{~mm}+1.0 \mathrm{ppm}$ for vertical positioning (kinematic); $2.5 \mathrm{~mm}+1.0 \mathrm{ppm}$ for horizontal and $5 \mathrm{~mm}+1.0$ ppm for vertical positioning (static). Points P6, P7 and P8 were located in the forest environments, but P5 was located in the unobstructed area (clear line of sight) (Pirti 2013).

As known, the forest canopy caused severe obstruction of the sky for these three points (especially for P6, P7 and P8 points) in the project area, see Figures 1,2 and 3. The problem shown by the sky plot of 10.30-15.30 hours for P6, P7 and $\mathrm{P} 8$ is typical for the whole day: several satellites were shaded by the forest, but were still tracked by the receivers see Figures $2 b, 2 c$ and $2 d$. However, all observed satellites for P5 point were not shaded due to the clear-line-of sight, see Figure 2a.

\section{RESULTS}

\section{REZULTATI}

\section{Static Processing - Statička obrada podataka}

Static data collection produces the most accurate and reliable results due to the amount of data collected during each observation. The disadvantage is in productivity. Long observations at each point reduce the number of points that 

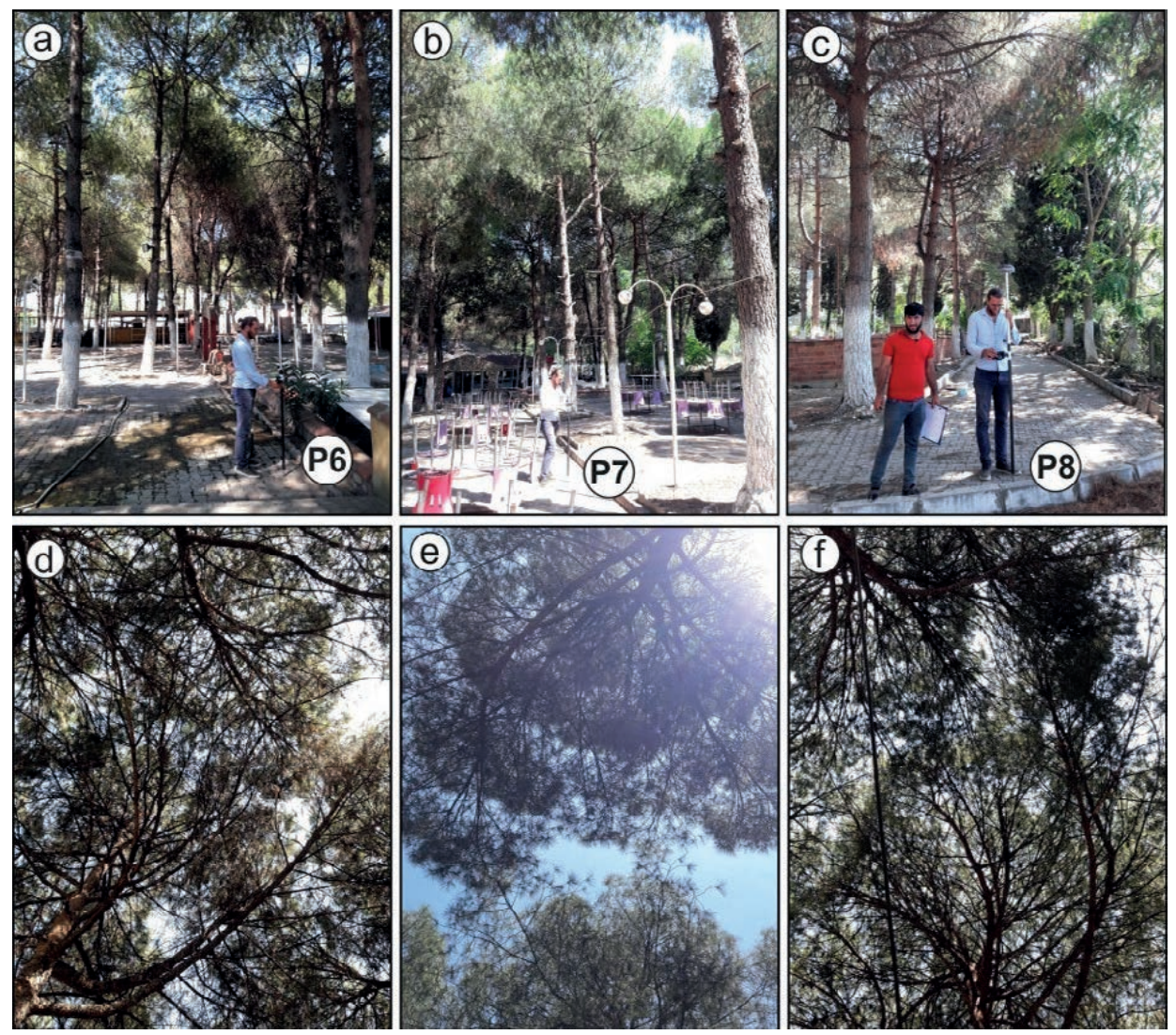

Figure 3. Points $P 6, P 7$ and $P 8$ in the study area $(a, b, c)$ and sky visibility from Points $P 6, P 7$ and $P 8(d, e, f)$, respectively Slika 3. Točke P6, P7 i P8 u području istraživanja $(a, b, c)$ i vidljivost neba s točaka P6, P7 i P8 (d, e, f)

can be collected in a day. The data processing and network adjustments were carried out using Topcon Magnet Tools Software. In the adjustment procedure, ITRF 2014 coordinates 2020.50 epoch of SALH point (CORS-TR point being used in Manisa) were held fixed (Table 1). The CORS-TR station SALH was about $28 \mathrm{~km}$ away from the project site, see Figure 1 (Pirti 2016), (El-Mowafy 2000), (Wolf 2008).

\section{Post-Process Kinematic (PPK) Method - \\ Postprocesna kinematička (PPK) metoda}

Although kinematic data collection has the advantage of high productivity, it has some disadvantages. Accuracy is not as well as with static data collection. The impact of the bad signal quality on the positioning results is naturally worse for kinematic positioning than for static processing occurs. Kinematic surveying can provide immediate results using the real-time kinematic mode or in the office using the post-process kinematic mode (Kaartinen 2015), (Pirti 2016), (El-Mowafy 2000), (Wolf 2008), (URL1).

\section{Horizontal Accuracy - Horizontalna točnost}

In the analysis, the static GNSS survey results were compared with PPK survey results. The PPK (epoch-by-epoch) derived coordinates of the four points (P5, P6, P7 and P8, see Figures 4, 5, 6 and 7) were compared with their coordinates as precisely determined by using static surveys. The static survey was performed to control and evaluate the performance of the PPK surveys. Figures 4, 5, 6 and 7 show the results of epoch-by-epoch kinematic processing (PPK) of about 5 hours session for the baselines SALH-P5, SALH-

Table 1. Coordinates and their standard deviations of the three points in ITRF 2014 coordinates 2020.5 epoch.

Tablica 1. Koordinate i standardne devijacije triju točaka s koordinatama ITRF 2014 u epohi 2020.5

\begin{tabular}{cccccccc} 
Name & $X(\mathrm{~m})$ & $\mathrm{Y}(\mathrm{m})$ & $\mathrm{H}(\mathrm{m})$ & $\mathrm{Std}(\mathrm{X})(\mathrm{m})$ & \multicolumn{2}{c}{$\operatorname{Std}(\mathrm{Y})(\mathrm{m})$} & \multicolumn{2}{c}{$\operatorname{Std}(\mathrm{H})(\mathrm{m})$} \\
SALH & 4261719,749 & 598034,370 & 156,060 & 0 & 0 & 0 \\
P5 & 4261910,870 & 569991,641 & 153,588 & 0,003 & 0,003 & 0,011 \\
P6 & 4261945,920 & 569916,745 & 156,332 & 0,003 & 0,003 & 0,012 \\
P7 & 4261963,134 & 569905,472 & 156,114 & 0,003 & 0,003 & 0,012 \\
P8 & 4261997,158 & 569894,426 & 155,314 & 0,004 & 0,004 & 0,015
\end{tabular}


P5
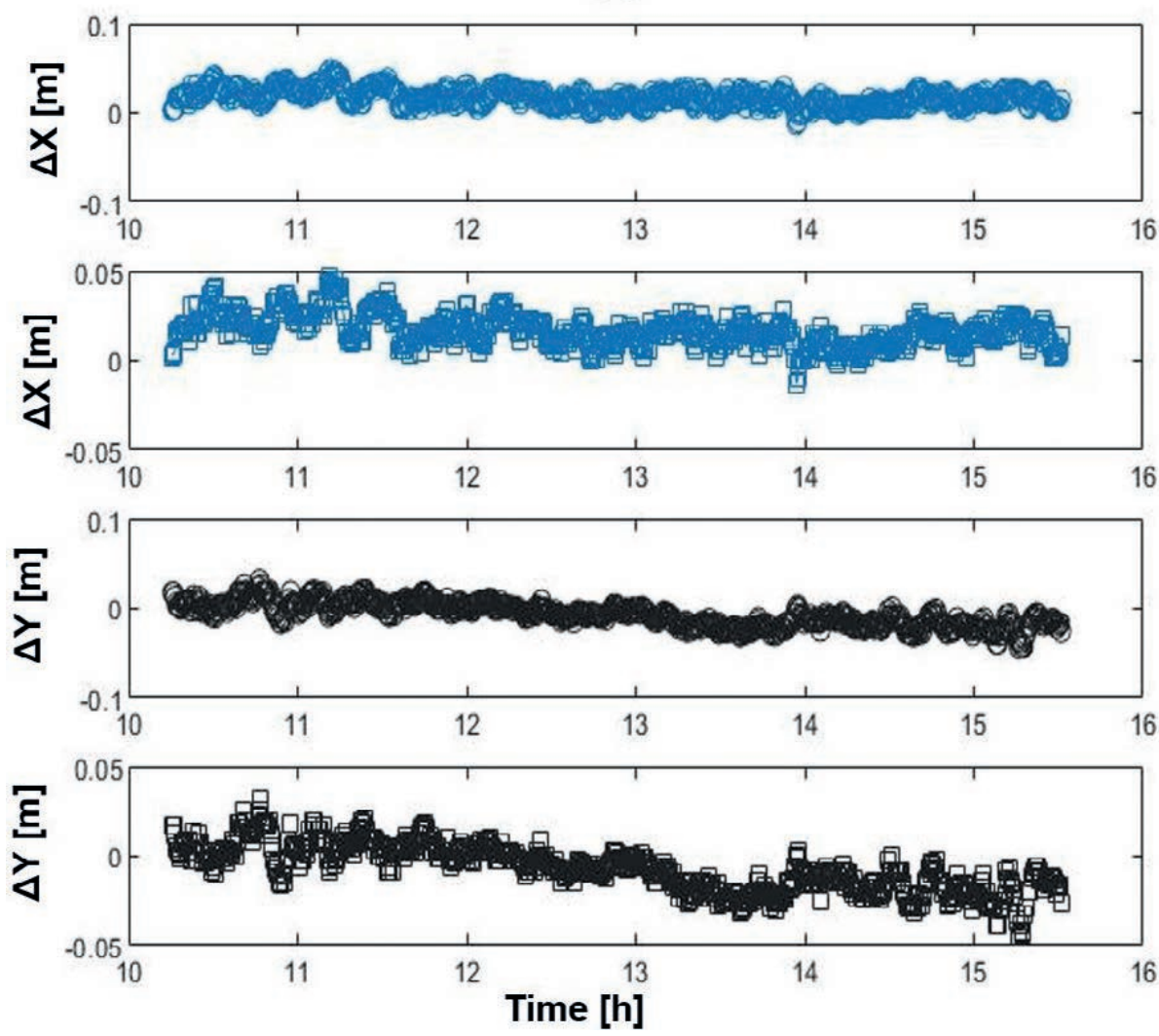

Figure 4. Epoch-by-epoch horizontal coordinate results of P5 point by using post-processed kinematic (PPK) module, deviation from static results. Slika 4. Rezultati horizontalnih koordinata za točku P5 epohu po epohu pomoću postprocesnog kinematičkog (PPK) modula, devijacija od statičkih rezultata

P6, SALH-P7, and SALH-P8 by using Topcon Magnet Tools Software. Figures 4, 5, 6 and 7 show the deviations for P5, P6, P7 and P8 points, in Easting (Y), Northing (X) coordinate directions. The comparison of the results of the PPK and static surveys for P5 point shows that the variations were generally about $\pm(1-10) \mathrm{cm}$ in horizontal coordinates between 10:30 hour and 15:30 hour, see Figure 4 . Between 10:30 hour and 15:30 hour, the integer ambiguity value fixed for all of this time period (10:30-15:30 hour) for P5 (clear line-of-sight). The horizontal coordinate differences at this time period between the PPK surveys and the static surveys differed up to about \pm (1-5) $\mathrm{cm}$, see Figure 4 .

The comparison of the results of the PPK and static surveys for P6 point shows that the variations were generally about $\pm(0-250) \mathrm{cm}$ in horizontal coordinates between 10:30 hour and 14:30 hour. The ambiguity solution not fixed at the period (between 10:15 and 11:00 hour, between 11:15 and 14:45 hours). The signal scattering due to the trees causes strongly fluctuating epoch results, with ranges of \pm (250 $\mathrm{cm}$ ) for the north and east components, see Figure 5. Between 11:00 and 11:15 hour; the integer ambiguity value fixed. The horizontal coordinate differences at these periods between the PPK surveys and the static surveys differed up to about $\pm(0-10) \mathrm{cm}$, see Figure 5 .
The comparison of the results of the PPK and static surveys for $\mathrm{P} 7$ point shows that the variations were generally about $\pm(0-150) \mathrm{cm}$ in horizontal coordinates between 10:30:00 hour and 15:30:00 hour (except for between 6:30-7:30 hour). The ambiguity solution not fixed at this period. The signal scattering due to the trees causes strongly fluctuating epoch results, with ranges of $\pm(0-150) \mathrm{cm}$ for the north and east components, see Figure 6. Between 10:45 hour and 11:00 hours, between 15:10 and 15:30; the integer ambiguity value fixed. The horizontal coordinate differences at this period between the PPK surveys and the static surveys differed up to about $\pm(0-10) \mathrm{cm}$, see Figure 6 .

The comparison of the results of the PPK and static surveys for $\mathrm{P} 8$ point shows that the variations were generally about $\pm(0-200) \mathrm{cm}$ in horizontal coordinates between 10:30:00 hour and 15:30:00 hour (except for between 11:30-11:45 hour). The ambiguity solution not fixed at this period. The signal scattering due to the trees causes strongly fluctuating epoch results, with ranges of $\pm(0-200) \mathrm{cm}$ for the north and east components, see Figure 7. Between 11:30 hour and 11:45 hours; the integer ambiguity value fixed. The horizontal coordinate differences at this period between the PPK surveys and the static surveys differed up to about \pm $(0-10) \mathrm{cm}$, see Figure 7. 
P6
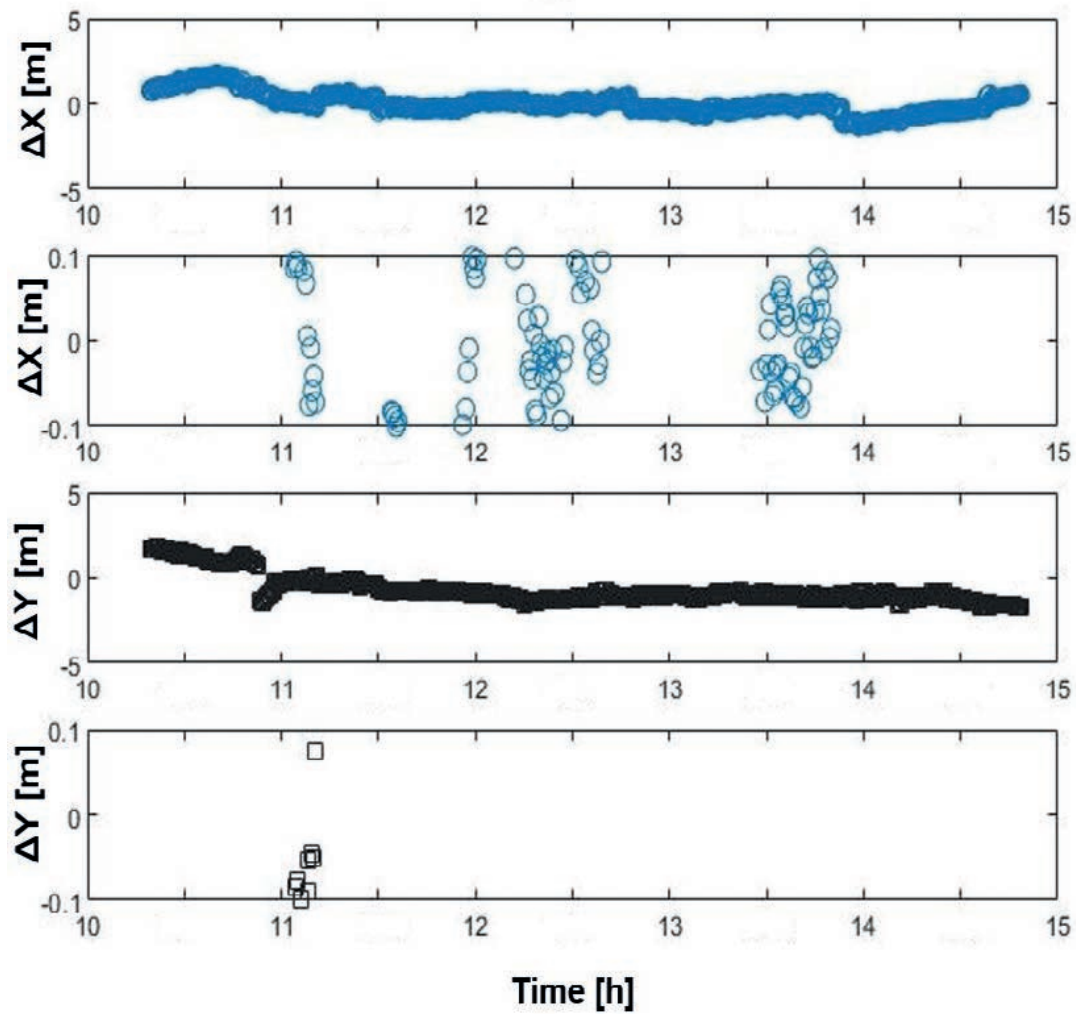

Figure 5. Epoch-by-epoch horizontal coordinate results of P6 point by using post-processed kinematic (PPK) module, deviation from static results. Slika 5. Rezultati horizontalnih koordinata za točku P6 epohu po epohu pomoću postprocesnog kinematičkog (PPK) modula, devijacija od statičkih rezultata
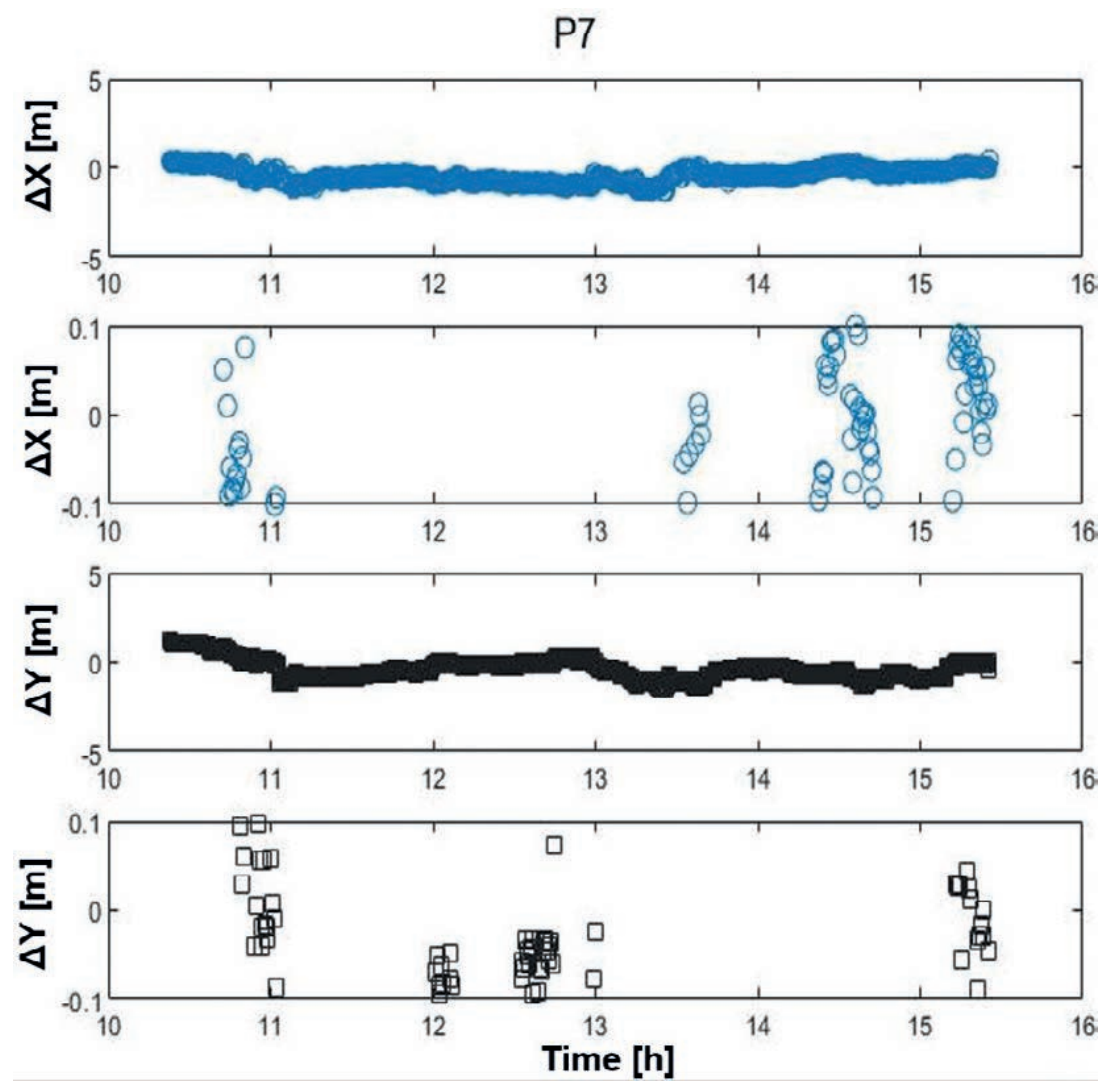

Figure 6. Epoch-by-epoch horizontal coordinate results of P7 point by using post-processed kinematic (PPK) module, deviation from static results. Slika 6. Rezultati horizontalnih koordinata za točku P7 epohu po epohu pomoću postprocesnog kinematičkog (PPK) modula, devijacija od statičkih rezultata 
P8
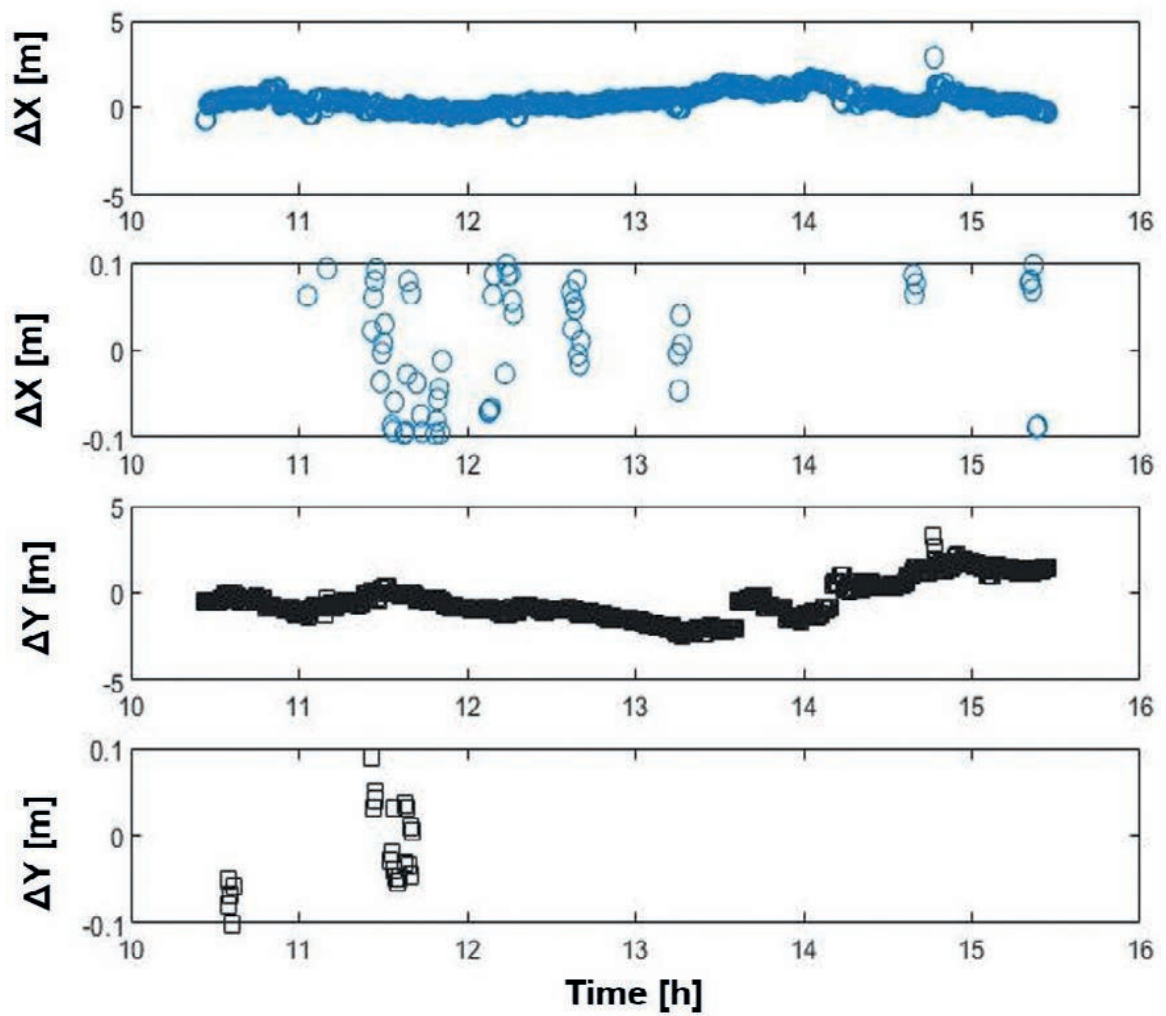

Figure 7. Epoch-by-epoch horizontal coordinate results of P8 point by using post-processed kinematic (PPK) module, deviation from static results. Slika 7. Rezultati horizontalnih koordinata za točku P8 epohu po epohu pomoću postprocesnog kinematičkog (PPK) modula, devijacija od statičkih rezultata
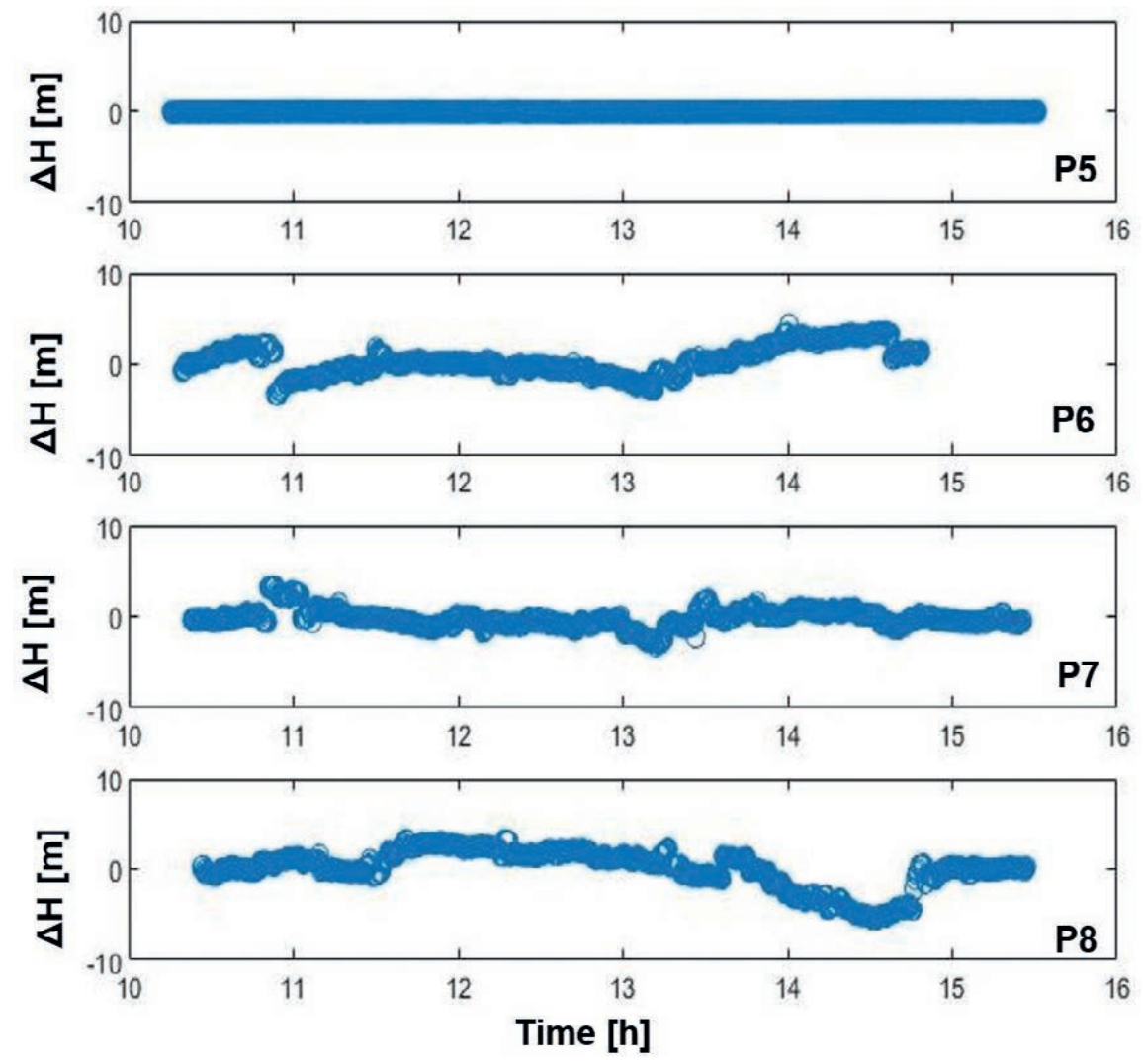

Figure 8. Epoch-by-epoch vertical coordinate differences results of four points by using post-processed kinematic module, deviation from static results Slika 8. Rezultati razlika u vertikalnim koordinatama za četiri točke epohu po epohu pomoću postprocesnog kinematičkog modula, devijacija od statičkih rezultata. 

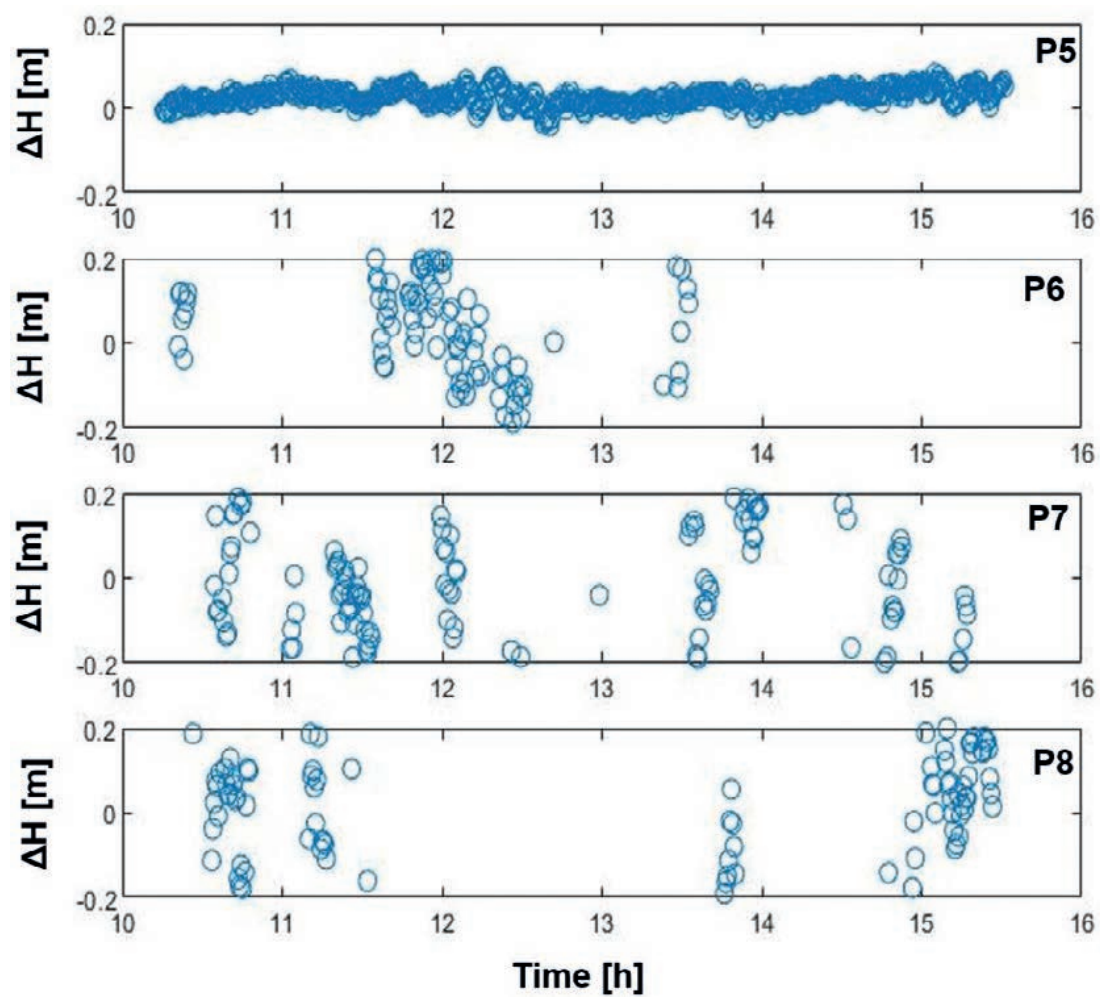

Figure 9. Epoch-by-epoch vertical coordinate differences results of four points by using post-processed kinematic module, deviation from static results (below $20 \mathrm{~cm}$ )

Slika 9. Rezultati razlika u vertikalnim koordinatama za četiri točke epohu po epohu pomoću postprocesnog kinematičkog modula, devijacija od statičkih rezultata (manje od $20 \mathrm{~cm}$ ).
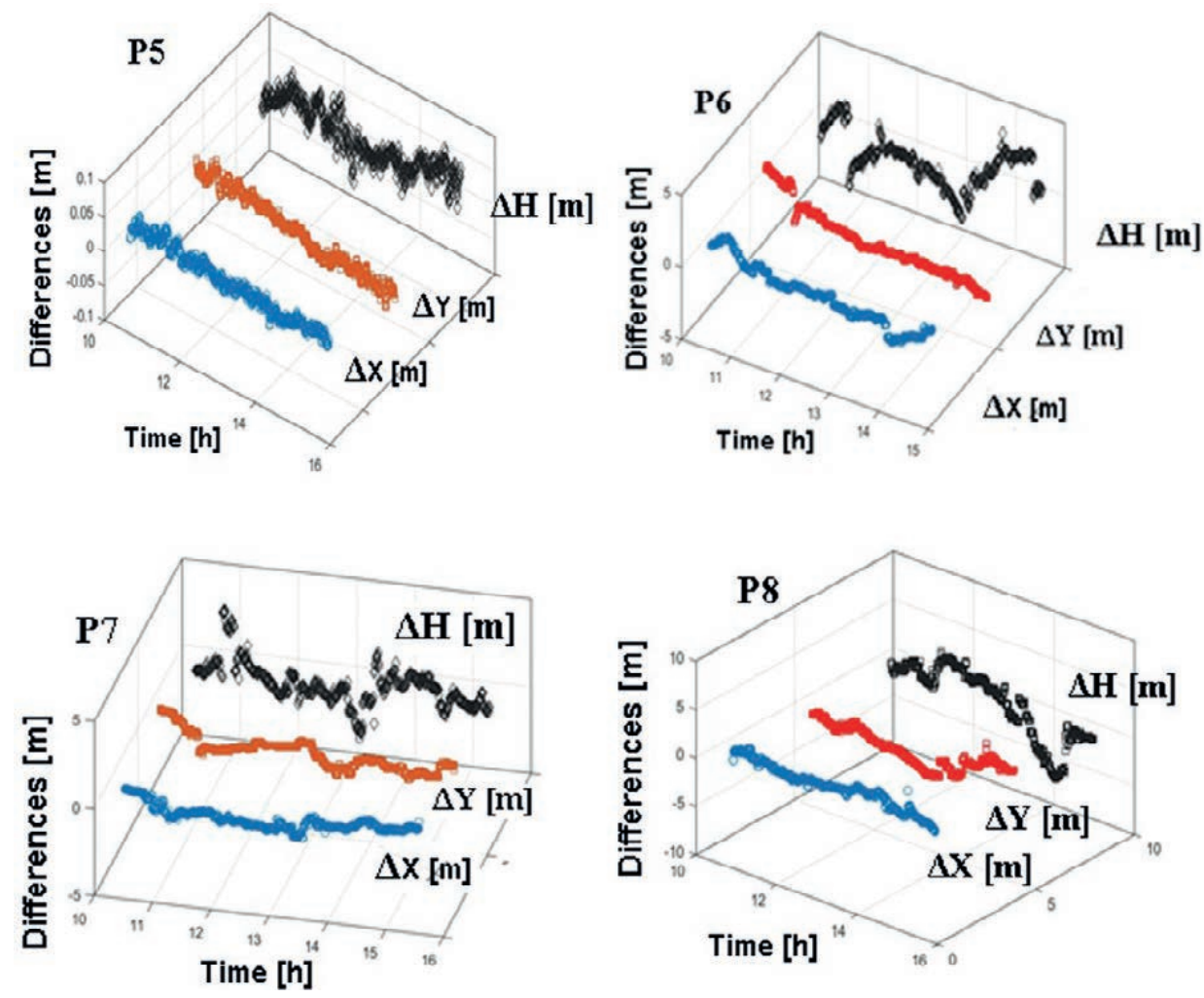

Figure 10. Epoch-by-epoch all of three-dimensional coordinate differences results of four points by using post-processed kinematic module, deviation from static results

Slika 10. Rezultati razlika svih trodimenzionalnih koordinata za četiri točke epohu po epohu pomoću postprocesnog kinematičkog modula, devijacija od statičkih rezultata. 


\section{Vertical Accuracy - Vertikalna točnost}

The comparison of the results of the PPK and static surveys for P5, P6, P7 and P8 points show that the variations were generally about $\pm(8-272) \mathrm{cm}$ in vertical coordinates between 10:00 hour and 15:30 hour, see Figure 8 (except for 11:30-11:45 hours). The ambiguity solution not fixed at this time period. Between 11:30 hour and 11:45 hours, the integer ambiguity value fixed. The vertical coordinate differences at this period between the PPK surveys and the static surveys differed up to about $\pm 20 \mathrm{~cm}$, see Figure 9 .

The comparison of the results of the PPK and static surveys for $\mathrm{P} 5$ point shows that the variations were generally about $\pm(1-10) \mathrm{cm}$ in three dimensional coordinates between 10:30 hour and 15:30 hour, see Figure 10. The comparison of the results of the PPK and static surveys for P6, P7 and $\mathrm{P} 8$ points shows that the variations were generally about \pm $(0-1000) \mathrm{cm}$ in three dimensional coordinates between 10:30 hour and 15:30 hour. The signal scattering due to the trees causes strongly fluctuating epoch results for three points, with ranges of $\pm(0-1000) \mathrm{cm}$ for the north, east and height components, see Figure 10. The impact of the bad signal quality on the positioning results is naturally worse for kinematic positioning than for static processing occurs.

The coordinate differences at the certain time intervals for P6, P7 and P8 points in the forest areas between the PPK surveys and the static surveys differed up to about $\pm(0-50)$ $\mathrm{cm}$, see Figure 11 .

\section{Consistency of the Static and PPK Results - Dosljednost statičkih i PPK rezultata}

To check the compatibility of the PPK technique with the static technique, the three dimensional (3D) misclosure vectors were computed as follows (Pirti 2013):

$$
m_{p}^{2}=\left(X_{P P K}-X_{\text {Static }}\right)^{2}+\left(Y_{P P K}-Y_{\text {Static }}\right)^{2}+\left(H_{P P K}-H_{\text {Static }}\right)^{2}
$$

$\mathrm{m}_{\mathrm{P}}$ is the misclosure vector (in metres) for all of the points, $\mathrm{Y}_{\mathrm{PPK}}$ and $\mathrm{X}_{\mathrm{PPK}}$ are the easting $(\mathrm{Y})$ and northing $(\mathrm{X})$ coordinates (in metres) of the four points from PPK survey coordinates, $\mathrm{Y}_{\text {Static }}$ and $\mathrm{X}_{\text {Static }}$ are the easting and northing coordinates of the four points (P5, P6, P7 and P8) from static surveys.

Figure 12 shows the horizontal misclose vectors for these four points. In this study the most important criteria in PPK measurement technique are survey time and fixed of the integer ambiguity value. Except for the partial and float ambiguity solutions for P5, P6, P7 and P8 points within forest and unobstructed environments (see Figure 12), the results clearly show that the PPK technique is a stable method and about $\pm(0-100) \mathrm{cm}$ level of accuracy is generally obtainable (Pirti 2009).
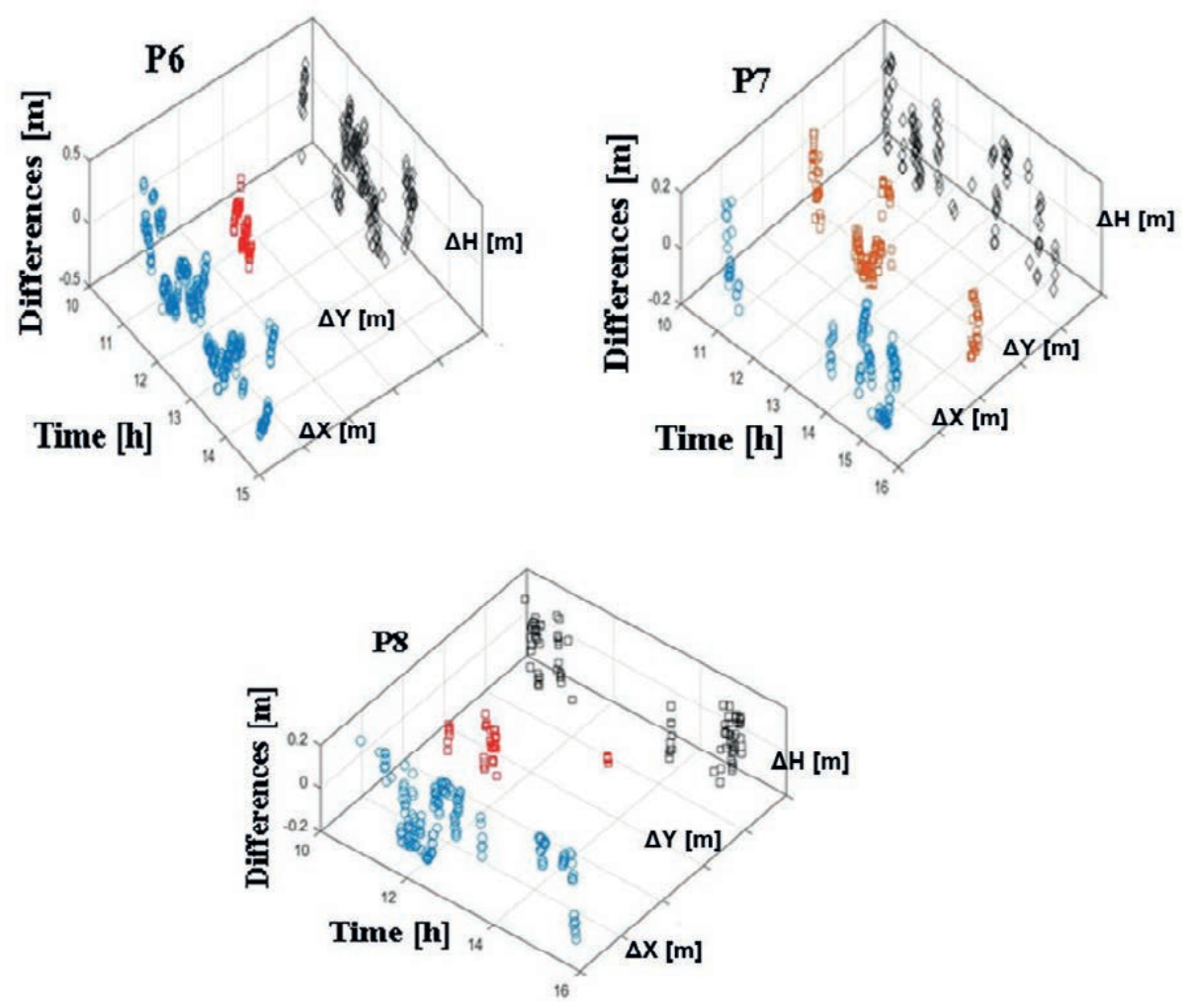

Figure 11. Epoch-by-epoch vertical coordinate differences results of three points (P6, P7 and P8) by using post-processed kinematic module, deviation from static results (below $50 \mathrm{~cm}$ for P6, $20 \mathrm{~cm}$ for P7 and P8)

Slika 11. Rezultati razlika vertikalnih koordinata za tri točke (P6, P7 i P8) epohu po epohu pomoću postprocesnog kinematičkog modula, devijacija od statičkih rezultata (manje od $50 \mathrm{~cm}$ za P6, $20 \mathrm{~cm}$ za P7 i P8). 

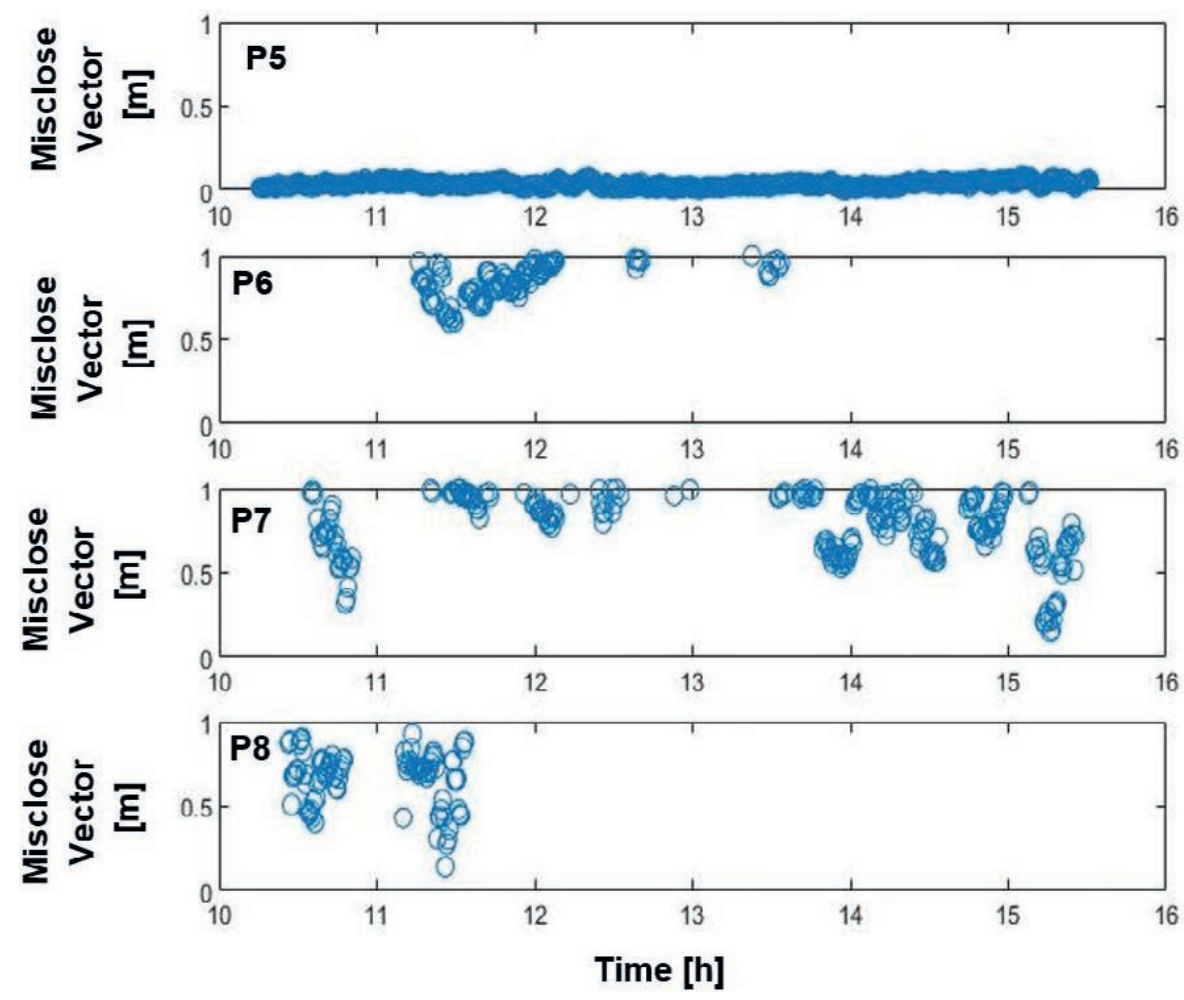

Figure 12. 3D misclosure vectors for all four points in the project area (below $1 \mathrm{~m}$ ) Slika 12. 3D pogreška zatvaranja vektora za sve četiri točke u području projekta (ispod $1 \mathrm{~m}$ )

\section{ZAKLJUČAK CONCLUSIONS}

GNSS use in forest environment that is particularly challenging to the CORS-GNSS signal reception due to multipath and direct signal blockages, which significantly affect the signal processing and further degrade the position accuracy and availability. PPK method is very efficient yet in difficult situations we are going to encounter certain accuracy problems. Forest environments should also be classified under difficulty situations. In this study the most important criteria in PPK measurement technique are survey time and fixed of the integer ambiguity value. To raise measurement reliability there, results from different resolutions of ambiguities should be used on each point. This would enhance survey reliability and accuracy. Nonetheless, it appears that forest measurements with $\pm 1 \mathrm{~cm}$ accuracy cannot be guaranteed on all occasions, since difficult situations may lead to greater errors for this study (about $\pm 0-10 \mathrm{~cm}$ accuracy for horizontal components and about \pm (0-100) $\mathrm{cm}$ accuracy for vertical components).

\section{LITERATURA}

\section{REFERENCES}

- El-Mowafy, Ahmed 2000: Performance Analysis of the RTK Technique in an Urban Environment. https://doi.org/10.1080/ 00050353.2000.10558803.
- Kaartinen H., Hyyppä J., Vastaranta M., Kukko A., Jaakkola A., Yu X., Pyörälä J., Liang X., Liu J., Wang Y., Kaijaluoto R., Melkas T., Holopainen M., Hyyppä H. 2015: Accuracy of kinematic positioning using Global satellite navigation systems under forest canopies. Forests 6(9): 3218-3236

- Pirti, A., Yucel, M.A., Gumus, K. 2013: Testing real time kinematic GNSS (GPS and GPS/GLONASS) methods in obstructed and unobstructed sites. Geodetski vestnik, 57- 83.

- Pirti, A. 2016: The seasonal effects of deciduous tree foliage in CORS-GNSS measurements (VRS/FKP). Tehnicki vjesnik Technical Gazette, 23(3), 769- 774. https://doi.org/10.17559/ TV-20150301214046

- Pirti, A., N. Arslan, B. Deveci, O. Aydin, H. Erkaya, and R. G. Hosbas. 2009: "Real-time Kinematic GPS for Cadastral Surveying." Survey Review 41 (314): 339-351. doi: 10.1179/ 003962609X451582

- Pirti, A. 2008: Accuracy analysis of GPS positioning near the forest environment. Croat. J. For. Eng. 29(2), 189-199

- Pirti A. 2005: Using GPS System near the Forest and Quality Control. Survey Review Journal 38(298): 286-298.

- Pirti, A., Gumus , K., Erkaya, H., and Gursel Hosbas , R. 2010: "Evaluating repeatability of RTK GPS/GLONASS near/under forest environment.” Croat. J. For. Eng., 31(1), 23-33.

- Wolf P.R. and C.D. Ghilani 2008: Elementary Surveying, An Introduction to Geomatics. 12th Edition, Prentice Hall Upper Saddle River, New Jersey, 960 p.

- Wright W.C., Wilkinson B.E., Cropper W.P. 2017. Estimating GPS Signal Loss in a Natural Deciduous Forest Using Sky Photography. Papers in Applied Geography 3(2): 119-128.

- URL1: https://d32ogoqmya1dw8.cloudfront.net/files/getsi/ teaching_materials/high-precision/static_gnss_survey_methods.v4.pdf 


\section{SAŽETAK}

GNSS uključuje konstelaciju satelita koji kruže oko Zemlje neprestano prenoseći signale koji omogućuju korisnicima da odrede svoj trodimenzionalni (3D) položaj s globalnom pokrivenošću. Princip pozicioniranja temelji se na rješavanju osnovnog geometrijskog problema koji uključuje udaljenost (raspon) od korisnika do niza od najmanje 4-5 GNSS satelita s poznatim koordinatama. Navedene udaljenosti i koordinate satelita određuju se pomoću korisnikovog prijamnika putem signala i navigacijskih podataka koje prenose sateliti; dobivene koordinate korisnika mogu se izračunati s odmakom od nekoliko metara. Međutim, centimetarski precizno pozicioniranje može se postići pomoću naprednijih tehnika (kinematičkih). GPS/GLONAS tehnika postaje obvezna u mnogim situacijama koje se tiču uređivanja šuma i izmjere. Cilj ovoga rada je usporedba koordinata dobivenih postprocesnom kinematikom s koordinatama za iste točke dobivene statičkom tehnikom. Usprkos tomu, čini se da se ne može jamčiti izmjera šume s preciznošću od $\pm 1 \mathrm{~cm}$ u svim slučajevima, budući da zahtjevne situacije mogu uzrokovati veće greške (preciznost od oko $\pm 10 \mathrm{~cm}$ za horizontalne komponente i oko $\pm(20-100) \mathrm{cm}$ za vertikalne komponente)

KLJUČNE RIJEČI: postprocesna kinematika, statika, šuma, točnost, preciznost 